\title{
Pembelajaran Efektif Pendidikan Agama Kristen Generasi Milenial
}

\author{
Active Learning Strategies of Christian Education \\ for Millennial Generation
}

\section{Mariani Harmadi}

Sekolah Tinggi Theologia Baptis Indonesia

mariani@stbi.ac.id

\author{
Abednego Agung Jatmiko \\ Mahasiswa Pascasarjana Sekolah Tinggi Theologia Baptis Indonesia \\ abedlokananta1976@gmail.com
}

\begin{abstract}
Article Info
\section{Abstract}

Submitted: Mei 11, 2020

Review: Mei 11, 2020

Accepted: Mei 27, 2020

\section{Keywords: \\ Christian education, era 4.0, \\ millennial generation, effective learning, education}

The portrait of education in Indonesia in the era of the industrial revolution 4.0 demands reforms to usher in millennials as a demographic bonus entering the Golden Indonesia era in 2045. They become a nation's children who are ready to compete in the era of globalization as well as free humans who are ready to collaborate for the common good on this earth. This paper aims to analyze reforms in the field of Christian Religious Education for millennials through effective learning methods. The analysis carried out qualitatively. The results obtained are, through effective learning methods, millennial children can educate according to the times by staying in the corridor of the word of God.
\end{abstract}

[Potret pendidikan di Indonesia pada era revolusi industri 4.0 menuntut reformasi demi mengantar generasi milenial sebagai bonus demografi memasuki era Indonesia Emas pada 2045 sehingga mereka menjadi anak bangsa yang siap bersaing di era globalisasi sekaligus sebagai manusia merdeka yang siap berkolaborasi untuk kebaikan bersama di muka bumi ini. Paper ini bertujuan menganalisis reformasi di dalam bidang Pendidikan Agama Kristen bagi generasi milenial melalui metode pembelajaran efektif. Analisis dilakukan secara kualitatif. Hasil yang diperoleh adalah, melalui metode pembelajaran efektif, anak-anak milenial dapat dididik sesuai perkembangan zaman dengan tetap berada di dalam koridor firman Tuhan.] 


\section{PENDAHULUAN}

$\mathrm{P}$ otret pendidikan di Indonesia ditinjau dari output dan jumlah pengangguran terbuka dicatat 6,82 juta orang terdiri dari: tidak pernah sekolah: 35.655 ; tidak tamat SD: 435.655; tamat SD: 954.010; tamat SMP: 1.219.767; tamat SMA: 1.680.794; tamat SMK: 1.381.964; tamat Diploma: 269.976; tamat Sarjana: 839.019. ${ }^{1}$ Data ini menunjukkan jumlah tertinggi pengangguran adalah lulusan SMA dan SMK dengan kisaran usia antara 18-20 tahunan yang termasuk generasi milenial. Padahal SisDikNas merancang lembaga pendidikan formal kejuruan ini dengan tujuan menghasilkan tenaga kerja yang terampil dan mampu mengembangkan potensi dirinya dalam perkembangan ilmu pengetahuan, teknologi, dan seni. ${ }^{2}$ Artinya dalam hal pembekalan pendidikan yang diselenggarakan bagi mereka belum menjawab tantangan dan persaingan serta kebutuhan pengguna tenaga kerja di era globalisasi ini.

Hal ini juga dikuatkan dengan data dari pendaftaran calon pegawai negeri sipil 2019 yang membuka lowongan untuk Pemerintah Pusat sebanyak 37.425 formasi dan pemerintah daerah 114.861 formasi. $^{3}$ Sementara jumlah pelamar sudah mendekati 5 juta orang yang dibuka pada 11 November 2019. ${ }^{4}$ Padahal generasi ini merupakan bonus demografi dengan jumlah sekitar $70 \%$ adalah penduduk Indonesia berada pada usia produktif (antara 15-64 tahun) pada tahun 2030 sampai tahun 2045. Jumlah yang diperkirakan 189 juta jika dihitung dari populasi penduduk sekarang kurang lebih 270 juta jiwa memerlukan lapangan pekerjaan, yang jika tidak tersedia maka berpotensi memicu konflik besar dan secara alami diikuti dengan kejahatan yang meningkat. Sehingga kurikulum pendidikan harus dirancang secara komprehensif dan terintegrasi antara kesiapan dan tantangan yang akan dihadapi khususnya di bidang ekonomi dimana semangat kewirausahaan perlu ditumbuhkan sedini mungkin sesuai dengan perkembangannya yang memadai.

Syamsuar \& Reflianto (2019) mengutip pendapat Musyaddad (2013) dari hasil penelitiannya yang mengungkapkan bahwa relevansi pendidikan dalam hal substansi dengan kebutuhan masyarakat masih tergolong rendah. Selain itu pendidikan justru dijadikan sebagai kawasan politisasi dari pejabat. Hal itulah yang memperparah ketidakmampuan pendidikan di Indonesia dalam menjawab tantangan di era industri 4.0. Mengenai bidang pendidikan yang sering dijadikan alat politik, menurut Groome, ${ }^{5}$ Plato dan Aristoteles juga berbicara mengenai pendidikan hanya dalam wilayah politik dimana pendidikan dilihat sebagai kegiatan yang bersifat politis untuk mempertahankan negara, seperti halnya juga yang dilakukan John Dewey yang menempatkan pendidikan sebagai sumber rekonstruksi sosial daripada pemeliharaan. Demikian juga Paulo Freire yang memandang tugas politis para pendidik yang autentik adalah memampukan orang-orang menghadapi realitas sosialmereka dengan kritis dan kreatif, daripada hanya menyesuaikan mereka dengan realitas sosial.

Pertanyaannya sampai sejauh mana kesalahan pendidikan yang dipolitisir sebagai alat kepentingan negara? Sering terdengar di tengah masyarakat komentar, "Ganti Menteri ganti kurikulum". Pergantian Menteri pada suatu pemerintah merupakan kewajaran dan kelaziman yang jika diiringi dengan pergantian kurikulum pun, bukan hal yang melanggar undang-undang selama tujuannya untuk mengusahakan dan menyelenggarakan sistem pendidikan nasional yang

\footnotetext{
${ }^{1}$ Agus Netral, "Bonus Demografi Dan Beban Pengangguran,” Kompasiana, last modified 2012, https://www.kompasiana.com/agusnetral6407/5db9435cd541df64e2390412/bonus-demografi-dan-bebanpengangguran?page=all.

2 "Salinan Lampiran I Peraturan Menteri Pendidikan Dan Kebudayaan Nomor 34 Tahun 2018 Tentang Standar Nasional Pendidikan Sekolah Menengah Kejuruan/Madrasah Aliyah Kejuruan Standar Kompetensi Lulusan," Jdih.Kemdikbud.Go.Id, https://jdih.kemdikbud.go.id/arsip/Permendikbud Nomor 34 Tahun 2018.pdf.

3 Tribunnews.Com, “Jumlah Pendaftar Dan Formasi Cpns 2019 accessed November 29, 2019,."

4 "Pendaftar CPNS Tembus 5 Juta Pelamar," Kompas. Com, last modified 2019, https://sains.kompas.com/read/2019/11/28/070106826/pendaftar-cpns-tembus-5-juta-pelamar-bkn-akanmaintenance-website.

5 Thomas H. Groome, Christian Religious Education. (Jakarta: BPK Gunung Mulia, 2011).
} 
meningkatkan keimanan dan ketakwaan kepada Tuhan Yang Maha Esa serta akhlak mulia dalam rangka mencerdaskan kehidupan bangsa yang diatur dengan undang-undang. ${ }^{6}$

Karena kurikulum merupakan jantungnya pendidikan yang vital untuk mewujudkan generasi penerus bangsa yang berdaulat, mandiri, dan berkepribadian melalui blue print dari grand design tersebut di tengah dinamika masyarakat yang terus bergejolak sehingga kurikulum perlu terus mengalami proses adaptasi untuk mengimbangi kebutuhan pergerakan dan tantangan zaman khususnya di era globalisasi revolusi industri 4.0 yang dialami oleh generasi milenial di tengah persilangan budaya yang berakibat culture-shock. Kurikulum merupakan rancangan semata yang memerlukan proses perwujudannya dengan mengatur strategi pembelajaran, memilih metode yang kreatif, media yang inovatif, evaluasi yang efektif, pelatihan para pendidik melalui sertifikasi atas keprofesionalannya dalam mengemban tugas sebagai pendidik.

Ditinjau dari kualifikasi akademik guru SD komposisinya didominasi lulusan D2 dan SPG sebanyak 83,10\% artinya belum mencapai kualifikasi minimal sesuai UU No. 20 Tahun 2003 tentang SisDikNas; UU No. 14 Tahun 2005 Tentang Guru dan Dosen; peraturan tentang kompetensi guru dalam PP No. 19 Tahun 2005 Pasal 28 ayat (3) yang ditetapkan sebagai agen pembelajaran yang kompeten pada jenjang pendidikannya meliputi kompetensi pedagogik, kepribadian, profesional, dan sosial. ${ }^{7}$ Juga kompetensi keprofesionalannya yang diatur UUGD Pasal 1 ayat 5 tentang kecakapan yang memenuhi standar mutu atau norma tertentu serta berkeahlian sesuai dengan standar mutu pendidikan yang ditetapkan oleh pemerintah dengan konteks era revolusi industri 4.0 ini membutuhkan kompetensi, 1) guru harus mampu melakukan penilaian secara komprehensif; 2) Guru harus memiliki kompetensi abad 21: karakter, akhlak dan literasi; 3) Guru harus mampu menyajikan modul sesuai passion siswa; dan 4) Guru harus mampu melakukan autentic learning yang inovatif. ${ }^{8}$

Gambaran situasi era industri 4.0 disebut oleh Gufron sebagai revolusi digital dan era disrupsi teknologi, yang mana revolusi digital terjadi karena proliferasi komputer dan otomatisasi pencatatan di semua bidang; artinya industri 4.0 sebagai fase revolusi teknologi ini akan mengubah cara manusia beraktifitas dalam skala, ruang lingkup, kompleksitas, dan transformasi dari pengalaman hidup sebelumnya, bahkan akan hidup dalam ketidakpastian global, sehingga manusia harus memiliki kemampuan untuk memprediksi masa depan yang berubah sangat cepat. ${ }^{9}$

Tujuan penelitian ini untuk merefleksikan keberlangsungan praktek pendidikan dengan media teknologi informasi pada era revolusi industri 4.0 yang walaupun belum merata di negeri ini, namun fenomena output atas disrupsi pendidikan terhadap pembentukan karakter telah terjadi sehingga praxis Pendidikan Agama termasuk Kristen yang ditetapkan dalam PP No. 55 Tahun 2007 Bab 2 Pasal $2(1)^{10}$ akan dikaji ulang.

\section{METODE}

Metode yang digunakan sifatnya praksis ${ }^{11}$ atau sebagai "tindakan reflektif" atas praktik yang diinformasikan oleh refleksi teoretis, atau sebaliknya, refleksi teoretis yang diinformasikan oleh praktik. Praksis berusaha mempertahankan teori dan praktik bersama-sama untuk saling memperkaya kegiatan manusia yang dilakukan dengan sengaja. Artinya riset ini akan melakukan tindakan reflektif atas praktik pendidikan yang sudah berlangsung dari hasil kajian teoretis tentang pembelajaran dengan media teknologi informasi yang perlu dievaluasi dalam konteks pembelajaran

\footnotetext{
${ }^{6}$ Undang-undang Republik Indonesia, Nasional.”, Nomor 20 Tahun 2003 Tentang Sistem Pendidikan, ( 2003).

${ }^{7}$ A. Hasan Saragih, "Kompetensi Minimal Seorang Guru Dalam Mengajar.” Jurnal Tabularasa, 5 (1). ISSN 1693-7732. Http://Digilib.Unimed.Ac.Id/715/ Diunduh 29 November 2019.

${ }^{8}$ Delipiter Lase, "Pendidikan Di Era Revolusi Industri 4.0," Sunderman ISSN:1979- (1979).

${ }^{9}$ MA Ghufron, "Revolusi Industri 4.0: Tantangan, Peluang Dan Solusi Bagi Dunia Pendidikan." in Seminar Nasional Dan Diskusi Panel Multidisiplin Hasil Penelitian \& Pengabdian Kepada Masyarakat. (Jakarta, 2018).

10 “PP No. 55 Tahun 2007,” BPK.Go.Id, https://peraturan.bpk.go.id/Home/Details/4777/pp-no-55tahun-2007.

${ }^{11}$ Groome, xxiii
} 
Pendidikan Agama Kristen demi mengantisipasi disrupsi atas fungsi dan tujuannya untuk memperkaya pengembangan kemampuan peserta didik dalam memahami, menghayati, dan mengamalkan nilai agama Kristen yang menyerasikan penguasaannya dalam ilmu pengetahuan, teknologi dan seni.

\section{PEMBAHASAN}

Fenomena ekses negatif dari disrupsi teknologi dengan penyalahgunaan internet oleh remaja telah berakibat pada tindak kriminal, kegalauan yang berujung pada keputus-asaan, keterasingan dari pergaulan sosial, dan konsep ekonomi yang kurang cermat dalam penggunaan uang, seperti kecanduan jejaring sosial yang berakibat pada penggunaan waktu dan uang secara mubazir serta menjalin pertemanan dengan orang asing yang berakibat pada tindak kriminal seperti perolehan hasil survei Online Survival Guide Consumer Reports secara global per September 2005 yang mendapati $47 \%$ responden mengaku menerima konten serta pesan sampah (spam) bernada pornografi dan diperkirakan lebih dari dua juta anak secara tak sengaja melihat pesan sampah bernada porno itu. Riset Finkelhor, Mitchell \& Wolak dari Online Victimazation pada Juni 2000 mencatat enam dari sepuluh remaja usia belasan menerima e-mail atau pesan instan (IM) dari orang yang tak dikenal, di mana $63 \%$ diantaranya mengaku direspon balik. ${ }^{12}$ Hal ini terjadi juga di Indonesia, seorang Direktur RSJ Jabar mendapati kecanduan penggunaan gawai tidak hanya dialami usia produktif tetapi juga anak-anak, bahkan saat ini anak-anak usai lima tahun sudah mengalami masalah kejiwaan akibat kecanduan gadget, dimana masalah kecanduan gawai pada anak-anak membuat usia rentan masalah kejiwaan meluas karena biasanya usia rentan minimal 15 tahun saat ini menjadi lima tahun. ${ }^{13}$ Selain juga dilaporkan adanya 10 Kematian tragis yang disebabkan smartphone. ${ }^{14} 9$ Kasus Pembunuhan Akibat Video Game. ${ }^{15}$ Perekrutan pengikut paham radikalisme dan terorisme menggunakan internet dengan berbagai tawaran yang menggiurkan dengan janji-janji palsu seperti kesempatan kerja di luar negeri padahal setelah tiba di tempat tujuan menjalani pelatihan militerisme, a.l. membuat senjata api, merakit bom, strategi perang, dll. ${ }^{16}$

Model praksis memberi ruang yang lebih luas bagi pengungkapan budaya atas iman, dan pengungkapan iman dari perspektif lokasi sosial, juga sebagai suatu pemahaman tentang pergumulan kehadiran Allah dalam situasi khusus dan terbuka terhadap setiap perkembangan yang terjadi di mana saja dan dalam situasi apapun, karena pendidikan berlangsung dalam konteks yang terus berubah. Artinya misi Pendidikan Agama Kristen yang merupakan aksi, perlu melakukan refleksi secara periodik dan berkesinambungan sehingga pencapaian tujuan Pendidikan Agama Kristen yang merupakan usaha untuk mengantar peserta didik berkemampuan hidup sesuai dengan iman Kristen dan mengalami perjumpaan secara pribadi dengan Allah Sang Khalik, Tuhan Yesus dan Roh Kudus sebagai Penyerta untuk mengalami pertumbuhan iman dan berbuah dalam kehidupan pribadi, sesama, dan Kerajaan Surga untuk disaksikan kepada dunia atas segenap perubahan hidupnya secara mewujud. Selanjutnya untuk mengenali makna dari pendidikan agama Kristen itu sendiri yang bertanggung jawab untuk berkontribusi bagi perubahan sosial yang massive ini -perlu melakukan evaluasi dan kajian sesuai dengan kondisi input dan output sebagai realitas dalam mengemban Amanat Agung Tuhan Yesus “Ajarlah....” Mat. 28:19-20.

\footnotetext{
12 Angga Pramudya, "Penyalahgunaan Internet Di Kalangan Remaja," Academia, https://www.academia.edu/36272147/PENYALAHGUNAAN_INTERNET_DI_KALANGAN_REMAJA.

${ }^{13}$ Mukhlis Dinillah, "Duh! Gegara Kecanduan Gadget, Bocah 5 Tahun Di Jabar Alami Masalah

Kejiwaan."," https://news.detik.com/Berita-Jawa-Barat/d-4741179/Duh-Gegara-Kecanduan-Gadget-Bocah5-Tahun-Di-Jabar-Alami-Masalah-Kejiwaan,accessed 17 Mei 2020.

${ }^{14}$ Wardani Agustin Setyo, "Kematian Tragis Akibat Smartphone.,," https://www.liputan6.com/Tekno/Read/3022645/10-Kematian-Tragis-Akibat-Smartphone accessed $17 \mathrm{Mei}$ 2020.

15 Liputan 6, "9 Kasus Pembunuhan Akibat Video Game.” accessed 17 Mei 2020," https://www.liputan6.com/Citizen6/Read/2287867/9-Kasus-Pembunuhan-Akibat-Video-Game.

${ }^{16}$ Harmadi Mariani, "Kurikulum Pendidikan Agama Kristen Yang Adaptif Dan Antisipatif Di Era Revolusi Industri 4.0.” In Membangun Indonesia Di Era Revolusi Industri 4.0., (Jakarta: Universitas Kristen Indonesia, 2018).
} 
Kajian studi pustaka yang akan dilakukan yaitu dengan cara menganalisa fenomena dan realitas masyarakat dalam konteks pendidikan melalui pengenalan sejarah pergerakan revolusi industri mulai pada tingkat 1 sampai sekarang yang sedang berada pada era revolusi industri 4.0, sehingga menghasilkan sumbangsih bagi proses pembelajaran dengan hasil output yang mumpuni. Karena realitas peserta didik dalam masyarakat kekinian, prinsip dasar pembelajaran abad-21 merupakan payung besar perubahan sosial yang tetap membutuhkan kebenaran Firman Tuhan sebagai dasar pengajaran bagi kehidupan yang cerdas dalam hal IQ, EQ, SQ, QQ.

Generasi milenial merupakan anak bangsa yang akan menjadi generasi emas pada 2045 sebagai impian besar tentang Indonesia yang unggul, maju bersaing dengan bangsa lain sebagaimana harapan dan cita-cita 100 tahun Indonesia merdeka. Mereka hidup pada era globalisasi dalam suatu jaringan kerja global yang mempersatukan masyarakat secara bersamaan yang sebelumnya tersebar dan terisolasi ke dalam saling ketergantungan dan persatuan dunia. Artinya umat manusia di seantero muka bumi ini sekarang berada pada suatu jaringan yang saling terkait dan terkoneksi dengan media teknologi informasi. Menurut Antone ${ }^{17}$ globalisasi adalah suatu bentuk kolonialisasi baru (neocolonization), dengan efek negatif lebih banyak daripada efek positifnya, yang mana oleh Tung (2013:258) juga dikatakan bahwa dampak positif globalisasi antara lain, mudah memperoleh pengetahuan dan informasi, mudah melakukan komunikasi, mobilitas yang tinggi dalam bepergian, dst. Sedangkan dampak negatifnya antara lain informasi yang tidak tersaring, perilaku konsumtif, membuat sikap menutup diri, berpikir sempit, pemborosan pengeluaran, meniru perilaku buruk, dan mudah terpengaruh oleh hal yang tidak sesuai dengan kebudayaan suatu negara. Kolonisasi baru ini menunjukkan dirinya dalam bentuk dominasi ekonomi, agresi kebudayaan, imperialisme politik, degradasi ekologi, dan sekarang, suatu perang tanpa batas. (Hope, 2012:142).

Revolusi industry 1.0 yang diawali dengan penemuan mesin uap yang meningkatkan efektivitas tenaga manusia yang terus meningkat hingga kini berada pada era revolusi industri 4.0 dimana terjadi perubahan kolaborasi manufaktur intelegensia dan Internet of Thing sebagai penggerak konektivitas manusia yang mendisrupsi bidang ekonomi, politik dan sosial. Sehingga penggunaan komputerisasi dan robot akan menggantikan tenaga manusia yang akan berdampak pada meningkatnya pengangguran, hoax yang menyebar, silang budaya, kegamangan, dll. Era Revolusi Industri 4.0 mengalami puncaknya dengan kelahiran teknologi digital yang mendorong sistem otomatisasi sehingga layanan administrasi pemerintahan pun berbasis e-governance seperti rintisan Kemendag RI dengan menyediakan mesin layanan mandiri (ATM) dukcapil bagi kebutuhan administrasi masyarakat.

Perubahan yang pesat ini tidak terjadi dalam kurun waktu ribuan tahun seperti teori evolusinya Charles Darwin "On the Origin of Species" melainkan dalam waktu singkat dari offline ke online, dari realita ke virtual, dari media cetak ke media sosial, sehingga nilai-nilai, tatanan sosial, dan budaya pun terdampak seiring pudarnya nilai-nilai sosial yang dicirikan dengan perubahan gaya hidup generasi milenial seperti konsumerisme, dimana kondisi sosial ini menjadikan konsumsi sebagai pusat kehidupan dan tujuan hidup dengan membeli sesuatu yang hanya untuk kesenangan semata dan dikendalikan oleh hasrat untuk mengonsumsi dan kadang hanya untuk menaikkan gengsi atau persaingan yang tidak sehat karena pengaruh tayangan iklan dalam media sosial atau jaringan komunikasi visual yang menarik. Perubahan sosial adalah keniscayaan terhadap perilaku manusia berkaitan dengan kegiatan pemenuhan kebutuhan hidup, interaksi antar manusia dengan mesin, ilmu pengetahuan, dan teknologi. Dimana hal itu yang antara lain ekses negatif dalam bidang ekonomi dan kehidupan sosial yang diterpa oleh gelombang teknologi informasi ini.

Seperti yang dinyatakan oleh Prof. Clayton Christensen sang pencipta teori disrupsi yang mencengangkan dunia dengan prediksinya pada tahun 2014 bahwa $50 \%$ dari seluruh universitas di AS akan bangkrut dalam 10-15 tahun ke depan akibat universitas-universitas itu terdisrupsi oleh beragam terobosan inovasi seperti online learning dan MOOCs (Massive Online Open Courses). ${ }^{18}$

\footnotetext{
${ }^{17}$ Hope S. Antone, Pendidikan Kristiani Kontekstual: Mempertimbangkan Realitas Kemajemukan Dalam Pendidikan Agama (Jakarta: BPK Gunung Mulia, 2010).

18 Yuswohadi, "Nadiem Dan Disrupsi Pendidikan Kita," accessed May 18, 2020, https://www.yuswohady.com/2019/10/25/nadiem-dan-disrupsi-pendidikan-kita/.
} 
Selanjutnya Prof. Christensen juga menimbulkan kecemasan atas temuan disrupsi yang menerpa dunia pendidikan, yaitu: $65 \%$ anak-anak kita yang kini memulai sekolah nantinya bakal mendapatkan pekerjaan-pekerjaan yang saat ini belum ada; 75 juta (42\%) pekerjaan manusia akan digantikan oleh robot dan artificial intelligence pada tahun 2022 (World Economic Forum, 2018); $60 \%$ universitas di seluruh dunia akan menggunakan teknologi virtual reality (VR) pada tahun 2021 untuk menghasilkan lingkungan pembelajaran yang imersif. (Gartner, 2018).

Rhenald Kasali ${ }^{19}$ pun berpendapat bahwa era industri 4.0 ini memunculkan mobilisasi dan orkestrasi, dimana segala benda baik buatan alam maupun manusia terhubung dengan manusia dari pelbagai belahan dunia yang merupakan bagian dari interconnected society 6 pilar teknologi, yaitu: Internet of Things (IoT), Cloud Computing, Big Data analystic, Artificial Intelligence (AI), Super Apps, dan Broadband Infrastructure. Sehingga berpotensi terjadinya saling pengaruh dalam hal keyakinan iman seseorang atas pelbagai informasi yang masuk dan tanpa saringan selain kemampuan dirinya sendiri dalam mengkritisi informasi yang diperolehnya.

\section{Pendidikan Agama}

Daryanto \& Karim $^{20}$ menyoroti konteks pendidikan yang memungkinkan peserta didik mampu mengadaptasi pengalaman belajar dengan mengintegrasikan tool dan sumber digital demi memotivasi dan mengembangkan kreatifitas dalam lingkungan belajar yang bernuansa teknologi, sehingga dapat menimbulkan rasa ingin tahu dan mudah dilibatkan dalam proses pembelajaran bagi dirinya yang sesuai dengan minat dan kebutuhan serta tantangan yang dihadapi sehingga peserta didik merasakan kostumisasi dan personalisasi dalam aktivitas belajarnya. Berkaitan dengan perkembangan teknologi informasi yang berpotensi menimbulkan disrupsi, pemikiran Emile Durkheim $^{21}$ tentang moralitas, terutama terkait moralitas kolektif tidak dapat diabaikan karena amanat yang diemban sistem pendidikan nasional adalah untuk meningkatkan keimanan dan ketakwaan kepada Tuhan Yang Maha Esa serta akhlak mulia dalam rangka mencerdaskan kehidupan bangsa seperti yang ditetapkan dalam Undang-undang Republik Indonesia Nomor 20 Tahun 2003 tentang Sistem Pendidikan Nasional.

Moral yang didasarkan pada pengajaran agama tidak mungkin melahirkan manusia yang akan menghancurkan bumi serta peradaban kehidupan manusianya. Durkheim meneliti fakta sosial yang dibedakan ke dalam dua tipe, yakni fakta material (sesuatu yang berwujud seperti birokrasi dan hukum) dan fakta non material tidak memiliki wujud, seperti contohnya kultur dan institusi sosial. Fakta sosial non-material menjadi pemersatu masyarakat primitif, khususnya tentang moralitas bersama atau kesadaran kolektif. Berbeda dengan masyarakat modern yang pada satu sisi diperhadapkan kepada tingkat persaingan yang ketat namun juga dipersatukan oleh ikatan yang dibangun lewat pembagian kerja, yang membuat satu orang dan yang lainnya saling tergantung. Durkheim beranggapan bahwa agama tak lain adalah cara masyarakat untuk memperlihatkan dirinya sendiri dalam bentuk fakta sosial non-material. Sehingga pendidikan agama dalam kurikulum harus mendapat porsi yang memadai sebagai penyeimbang bagi kesehatan mental peserta didik mencapai kecerdasan IQ, EQ, SQ, QQ yang maksimal dan seimbang.

\section{Strategi Pembelajaran yang Efektif}

Menurut Yuswohadi, sekolah tradisional sebagai wahana pembelajaran akan tergeser dari posisi "core" menjadi "peripheral" sehingga proses pembelajaran tidak hanya berlangsung di kelas

${ }^{19}$ Wijayakusuma., "Masyarakat Masih Gagal Paham Dengan Perubahan Era Industri 4.0.”, accessed 13 Mei 2020."

https://today.line.me/Id/Pc/Article/Masyarakat+Masih+Gagal+Paham+dengan+Perubahan+Era+Industri $+4+0$ $-2 \mathrm{mmXGN}$.

${ }^{20}$ Daryanto and Syaiful Karim, Pembelajaran Abad 21, Gaya Media (Yogyakarta: Penerbit Gava Media, 2017).

${ }^{21}$ Wijayati Hasna, “Tokoh Sosiologi Emile Durkheim Dan Pemikirannya.," last modified 2017, https://portal-ilmu.com/tokoh-sosiologi-emile-durkheim/. 
melainkan juga dilakukan anytime, anywhere, any platform/device termasuk peran guru yang tidak hanya berada di kelas tetapi pelbagai sumber belajar merupakan guru yang diperankan oleh AI atau AR/VR. ${ }^{22}$ Dalam hal ini sampai sejauh mana efektivitas penyelenggaraan pendidikan agama Kristen dengan kondisi seperti pandangan Yuswohadi di atas?

Tentu saja dampak globalisasi terhadap penguasaan teknologi informasi menimbulkan dorongan untuk melahirkan sumber daya manusia yang unggul, komperatif dan kompetitif, sehingga bagi negeri ini orientasi pendidikan pun fokus terhadap output yang menjunjung semangat kebangsaan dalam kehidupan berdemokrasi dan bertanggung jawab terhadap negara dengan revolusi mental yang berpikir "Apa yang akan disumbangkan saya kepada negara, bukan apa yang saya dapat dari negara?" sesuai pidato Pendiri NKRI, Soekarno.

Pemerintah cq Kemendikbud memfasilitasi pendidikan Agama Kristen dan mata pelajaran lainnya yang memadai bagi fasilitas belajar peserta didik yang merupakan native-digital dengan mendirikan Rumah Belajar yang merupakan portal pembelajaran dengan menyediakan bahan belajar serta fasilitas komunikasi yang mendukung interaksi antar komunitas sehingga belajar dapat dilakukan di mana saja, kapan saja dengan siapa saja seperti motto Ki Hajar Dewantara di laman beranda yang berbunyi "Jadikan setiap tempat sebagai sekolah, jadikan setiap orang sebagai guru". Kemendikbud melalui Pusat Teknologi Informasi dan Komunikasi Pendidikan dan Kebudayaan (Pustekkom) mengembangkan portal ini sebagai salah satu usaha untuk memfasilitasi proses pembelajaran melalui media jaringan atau secara online yang menyediakan konten-konten multimedia pembelajaran sebagai sumber belajar dan fasilitas pembelajaran jarak jauh secara online melalui fitur Kelas Maya yang merupakan sebuah learning management system (LMS) melalui alat komunikasi synkronous (chat, video conference, audio conference, desktop sharing, whiteboard). Strategi pembelajaran di Kelas Maya lebih bersifat konstruktivistik yang menuntut pembelajaran aktif dan berpusat pada peserta didik.

Sependapat dengan pandangan Zaluchu bahwa instrumentasi dan integrasi adalah jawaban bagi upaya memperbaiki sistem pendidikan generasi milenial. Tetapi dalam hal ini pengertiannya bukan sekedar dengan melatih guru untuk menggunakan internet, memasang Wi-Fi gratis di sekolah melainkan perubahan pola pikir digital yang menjadi dasar atau titik tolak terjadinya transformasi untuk mendigitalkan sistem pendidikan. ${ }^{23}$ Karena media digital berbasis internet hanya sebuah sarana dalam pembelajaran semata, sedangkan pendidik yang berperan sebagai pengguna yang dapat mengembangkan strategi bagi pendidikan Agama Kristen, antara lain: browsing atau searching pengetahuan iman; chatting, mailing list, dan jejaring sosial; blogging pengetahuan dan pengalaman iman; e-learning pendidikan iman; dan bila memungkinkan menciptakan robotik untuk mendukung pelayanan bagi pengembangan pengetahuan dan pengalaman iman. ${ }^{24}$

Era revolusi industri 4.0 di bawah pengaruh teknologi informasi yang massive ini memerlukan aksi atas hasil refleksi untuk mengkaji ulang pendidikan sesuai dengan ciri model, aktivitas jalinan antara aksi dan refleksi yang berjalan terus dengan menghasilkan pemahaman yang baru. Hal ini penting untuk mengetahui tindakan yang tepat bagi pengembangan pendidikan pada masa sekarang dan masa depan. Model praksis tidak pernah terlepas dari konteks, yaitu situasi lingkungan pendidikan yang dikawinkan dengan sebuah konteks khusus yang dalam hal ini konteks pendidikan Agama Kristen. Namun mempertimbangkan untuk mengadopsi strategi pembelajaran dari para ahli di bidang ilmu lain pun merupakan kecerdasan selama hal itu tidak bertentangan dengan kebenaran Alkitab. Sehingga 7 skills yang disebut penentu kesuksesan anak pada abad-21 gagasan Tony Wagner (2008) yang dikutip Tantri ${ }^{25}$ berikut ini adalah sesuai dengan ciri-ciri karakter generasi

${ }^{22}$ Yuswohadi, "Nadiem Dan Disrupsi Pendidikan Kita."

${ }^{23}$ Sonny Zaluchu, "The Digital Mindset as an Approach to Education Forthe Millenial Generation," in ICOGESS, ed. Suardin Gaurifa (Medan: EAI, 2020), https://eudl.eu/doi/10.4108/eai.14-3-2019.2292036.

${ }^{24}$ Kristianto Paulus Eko, "Menjadi Homo Informaticus: Pendidikan Agama Kristen Untuk Remaja

Di Era Kecerdasan Buatan."," in Membangun Indonesia Di Era Revolusi Industri 4.0 (Jakarta: Universitas Kristen Indonesia, 2018), 300.

${ }^{25}$ Tantri Novita Merdiana, Efektivitas Kurikulum 2013 Bagi Sekolah Menengah Kejuruan Dan Tantangan Revolusi Industri 4.0." In Membangun Indonesia Di Era Revolusi Industri 4.0 (Jakarta: Universitas Kristen Indonesia, 2018) 34. 
milenial, yaitu: 1) critical-thinking \& problem solving; 2) Collaboration across networks \&leading by influence; 3) Agility \& adaptability; 4) initiative \& entrepreneurialism; 5) effective oral \& written communication; 6) accessing \& analyszing information; 7) curiousity \& imagination.

Beberapa solusi yang bisa dilakukan antara lain, kesesuaian kurikulum dan kebijakan dalam pendidikan, kesiapan SDM dalam memanfaatkan ICT, mengoptimalkan kemampuan peserta didik, dan mengembangkan nilai - nilai (karakter) peserta didik, serta dan kesiapan sarana dan prasarana pembelajaran berbasis digital. ${ }^{26}$ Hal lain yang penting dipertimbangkan bagi pendidikan agama Kristen adalah pendapat Sijabat. ${ }^{27}$ yang merumuskan usulan strategi pendidikan yaitu 4 aktivitas belajar, antara lain aktivitas olah hati dan aktivitas olah rasa dan karsa yang paling terkait dengan pendidikan moral dan agama dibanding kegiatan olah pikir dan olah raga. Dimana aktivitas olah hati (emotional activities) bertujuan untuk membangun karakter jujur, beriman, taqwa, amanah, adil, bertanggung jawab, berempati, berani mengambil resiko, pantang menyerah, rela berkorban dan berjiwa patriotik. Sedangkan aktivitas olah rasa dan karsa (affective activities) bertujuan untuk memunculkan dan membiasakan karakter peduli, ramah, menghargai, suka menolong, gotong royong, nasionalis, mengutamakan kepentingan umum, bangga menggunakan produk dan bahasa nasional, dinamis, kerja keras dan beretos kerja. Dengan demikian sesuai dengan tujuannya pendidikan Agama Kristen dapat mengefektifkan strategi pembelajaran pada ranah tersebut sehingga generasi milenial yang berada pada persilangan budaya tidak kehilangan identitas diri sebagai anak bangsa yang berbudaya adiluhung dan berkeyakinan teguh kepada Tuhan Yang Maha Esa.

Sedangkan Sudrajat ${ }^{28}$ mengutip prinsip pembelajaran abad-21 yang dirumuskan oleh Jenifer Nichols 4 Essential of 21 st Century Learning, namun tiga diantaranya (prinsip pertama, kedua dan keempat) yang paling efektif bagi penyelenggaraan pendidikan agama Kristen, yaitu: Pertama, Instruction should be student centered artinya peserta didik dilibatkan dalam pengembangan program belajarnya sesuai dengan tantangan dan tuntutan yang dihadapi melalui teknologi dan internet sehingga peserta didik memiliki ruang gerak sosial yang luas sampai menembus pelbagai belahan dunia. Sehingga strategi, metode, media pembelajaran pun dapat mengefektifkan teknologi secara kreatif dan inovatif, antara lain metode blended-learning, media e-learning, e-book, dll sekaligus untuk membantu peserta didik menjadi warga digital yang bertanggung jawab. Kedua, educaton should be collaborative artinya peserta didik dikondisikan dalam pembelajaran yang berkolaborasi dengan orang lain untuk saling melengkapi dengan mengembangkan kecerdasan sosialnya dalam membangun jaringan yang luas dan mampu bekerja sama dalam tim. Karena pada dasarnya setiap orang memiliki kecerdasan alamiah yang lebih dominan dan berbeda satu dengan yang lain seperti teori Howard Gardner ${ }^{29}$ dalam Multiple Intellegences yang terdiri dari: kecerdasan linguistik (berkaitan dengan bahasa); kecerdasan logis-matematis (berkaitan dengan nalar-logika dan matematika); kecerdasan spasial (berkaitan dengan ruang dan gambar); kecerdasan musikal (berkaitan dengan musik, irama dan bunyi/suara); kecerdasan badani-kinestetik (berkaitan dengan badan dan gerak tubuh); kecerdasan interpersonal (berkaitan dengan hal-hal yang sangat pribadi). Sehingga dengan pelbagai kecerdasan yang dikoordinir untuk bekerja dalam tim merupakan cara yang efektif untuk memberikan hasil yang maksimal, dengan asumsi bahwa selama dalam proses interaksi telah terjadi seperti debat, kritik, saran, usul dari antara satu dengan yang lain sehingga membutuhkan kebesaran jiwa atau lapang dada untuk membentuk ketahanan mental yang kuat dengan mengasah kecerdasan emosi dan sosialnya. Proses belajar ini sekaligus merupakan penanaman benih toleransi dan solidaritas serta tenggang rasa terhadap pelbagai perbedaan latar

${ }^{26}$ Syamsuar and Reflianto, "Pendidikan Dan Tantangan Pembelajaran Berbasis Teknologi Informasi Di Era Revolusi Industri 4.0," Pendidikan Dan Tantangan Pembelajaran Berbasis Teknologi Informasi Di Era Revolusi Industri 4.0 6, no. 2 (2019): 1-13.

${ }^{27}$ Binsen Samuel Sidjabat, "Kerangka Kurikulum Pendidikan Agama Kristen Berbasis Karakter Di Perguruan Tinggi Character-Based Christian Religious Education Curriculum Framework in Higher Education," Jurnal Jaffray 17, no. 1 (2019): 73-90.

${ }^{28}$ Sudrajat Akhmad, ““‘4 Prinsip Pokok Pembelajaran Abad Ke-21., accessed 29 November 2019” https://akhmadsudrajat.wordpress.com/2013/10/01/Prinsip-Pembelajaran-Abad-Ke-21/.

29 J Jasmine - Bandung: Nuansa Cendekia and Undefined 2012, Metode Mengajar Multiple Intelligences (Bandung: Penerbit Nuansa, 2016). 
belakang, budaya, ras, bahasa, strata ekonomi, agama/keyakinan, gender, dan nilai-nilai yang dianutnya. Keempat, school should be integrated with society artinya sekolah harus berintegrasi dengan masyarakat melalui upaya mempersiapkan peserta didik sebagai anggota masyarakat yang bertanggung jawab dalam keterlibatannya sebagai warga negara, antara lain tugas pengabdian masyarakat yang difungsikan secara maksimal bukan hanya sekedar memenuhi tuntutan SKS semata dengan mengambil peran dan tanggung jawab sesuai dengan kapasitasnya, seperti penanganan masalah ekologi, climate change, pengelolaan tanah, pelestarian budaya, dll. untuk mengasah kepedulian terhadap masalah sosial dan kerusakan lingkungan alam.

Gufron mengutip Irianto dari Forum ekonomi dunia melansir tentang struktur keterampilan abad 21 yang akan mengalami perubahan antara struktur tahun 2015 dengan tahun 2020. Namun kedua rangkaian struktur ketrampilan tersebut terkait erat dengan proses pendidikan agama Kristen, yaitu tahun 2015 terdiri dari 1) pemecahan masalah yang kompleks; 2) kerjasama dengan orang lain; 3) manajemen orang; 4) berpikir kritis; 5) negosiasi; 6) kontrol kualitas; 7) orientasi layanan; 8) penilaian dan pengambilan keputusan; 9) mendengarkan secara aktif; dan 10); kreativitas. Sementara struktur ketrampilan tahun 2020 meliputi 1) pemecahan masalah yang kompleks; 2) berpikir kritis; 3) kreativitas; 4) manajemen orang; 5) kerjasama dengan orang lain 6) kecerdasan emosional; 7) penilaian dan pengambilan keputusan; 8) orientasi layanan; 9) negosiasi; dan 10) fleksibilitas kognitif (Irianto, 2017). ${ }^{30}$ Dimana ke-20 struktur ketrampilan di atas merupakan unsur-unsur dari praksis pendidikan agama Kristen yang tidak terpisahkan atau terlalu jauh berbeda dengan pendidikan pada umumnya.

Pandangan (Mulyana, 2018) dikutip Syamsuar \& Reflianto (2019) mengenai pendidikan umum yang membangun landasan kuat peserta didik untuk menjadikan sumber daya manusia (SDM) yang "memanusiakan manusia" pun selaras dengan pendidikan agama Kristen melalui proses berfikir, berperasaan, berkesadaran, bertindak, berperilaku dan beramal sesuai dengan keyakinan agama yang dianutnya. masing-masing. Sehingga tidak ada lagi berita tentang pemukulan siswa oleh guru atau bahkan sebaliknya, pelecehan seksual oleh guru terhadap siswanya juga hal yang sebaliknya; bullying (perundungan), hoaks (berita yang belum dapat dipertanggungjawabkan kebenarannya), cyber-crime (kejahatan dengan menggunakan teknologi digital seperti pengkloningan akun facebook, penyebaran virus, pencurian dan penjualan data, dll yang merupakan sisi lain dari potret pendidikan kita. Dimana kondisi perkembangan teknologi yang tidak disertai dengan pendidikan moral pun telah terbukti dari pengalaman orang belajar merakit bom melalui tutorial lewat internet yang digunakan untuk kejahatan seperti teroris, ekstrimis, dll.

Syamsuar dan Reflianto mengutip Kirschenbaum (1992) yang berpendapat bahwa pendidikan nilai pada dasarnya lebih ditujukan untuk memperbaiki moral bangsa, sehingga peserta didik mampu menentukan nilai baik dan buruk dalam kehidupan serta mampu memilih nilai yang baik untuk peningkatan kualitas hidupnya di tengah masyarakat. Gambaran peristiwa yang terjadi akhir-akhir ini merupakan output dari ketidak-cerdasan dalam membedakan nilai yang baik dan buruk atas pengaruh dari dunia maya melalui tontonan dari film horor, yaitu kasus pembunuhan seorang anak perempuan berusia 5 tahun oleh seorang remaja putri usia 15 tahun. Sehingga Vidyatama ${ }^{31}$ menawarkan suatu strategi dalam bidang pendidikan agama Kristen yaitu PAK ramah digital yang antisipatif terhadap teknologi digital dengan memanfaatkan sisi positifnya dengan membuat pembelajaran yang menarik secara visual, interaktif dan menantang, tetapi mencegah sisi negatif yang dapat menjadikan generasi yang lahir antara tahun 1995-2010 sebagai generasi langgas yang hilang dari gereja dan jauh dari jangkauan generasi sebelumnya karena adanya jurang pemisah di antara keduanya.

Kohlberg (2005) dalam Syamsuar \& Reflianto (2019) menyatakan bahwa pendidikan moral merupakan suatu upaya membantu peserta didik menuju satu tahap perkembangan dengan peran guru yang mengenalkan peserta didik terhadap pelbagai masalah konflik moral seperti konflik

\footnotetext{
${ }^{30}$ Ghufron, "Revolusi Industri 4.0: Tantangan, Peluang Dan Solusi Bagi Dunia Pendidikan."

${ }^{31}$ Vidyatama David, PAK Ramah Digital: Strategi Pendidikan Agama Kristen Bagi Generasi Z Di Gereja Baptis Indonesia Getsemani Jakarta.” In Membangun Indonesia Di Era Revolusi Industri 4.0., (Jakarta: Universitas Kristen Indonesia, 2018.)160.
} 
kepentingan dalam pengambilan keputusan yang diperhadapkan kepada dilema sehingga output mampu melewati tahap demi tahap tugas perkembangan hidupnya seperti yang diteorikan oleh Havighurst. Dengan demikian pendidikan harus berlangsung dalam just school environment artinya tidak hanya efektif melalui dunia maya (virtual) karena menyangkut nilai-nilai yang mulai tergerus akibat tranformasi industri 4.0, yaitu: (1) Nilai kultural berhubungan dengan budaya, karakteristik lingkungan sosial dan masyarakat (Djhiri, 2002) dimana output mampu mengenalinya dan mengembangkan keseimbangan yang sehat antara sikap terbuka (openness) dan tidak mudah percaya (skepticism). (2) Nilai yuridis formal berkaitan dengan aspek politik, hukum dan ideologi (Djahiri, 2002) yang merupakan rambu-rambu dalam bersikap dan berperilaku sosial serta berpolitik yang baik dan tidak beresiko dengan aspek akibat pelanggaran hukum. (3) Nilai religius merupakan pertahanan untuk menghadapi pelbagai tantangan termasuk krisis akibat dari perubahan sosial seperti revolusi industri 4.0 yang menggeser fungsi manusia dengan kecanggihan robotisasi.

Dalam kaitannya dengan perubahan sosial yang terjadi di dunia tanpa batas ini, para pendidik agama Kristen yang sebagian besar generasi baby-boomer (tahun kelahiran sebelum 1960-an) mampu menjadi penjaga generasi penerus dengan berpikir kritis dan kreatif serta mampu memaksimalkan sarana media digital berbasis internet dalam mengemban tugas pembelajaran. Agar peserta didik yang disebut juga sebagai generasi yang konsisten terhadap panggilan dan pengembanan amanat membimbing peserta didik berusaha sampai pada capaian mereka berpengalaman menjadi umat Allah dan menjadi murid Yesus Kristus serta mengalami transformasi (Rom. 12:1) sesuai esensi dan makna belajar yaitu berubah. Dasar Alkitab tentang status dan kesadaran diri merupakan perbandingan keadaan sebelum (yang dahulu) dan yang sesudahnya (sekarang) sebagai wujud proses transformasi internal (Kol. 1:21-22) yang menjadikan transformasi nilai personal berpengaruh dalam konteks masyarakat majemuk melalui sikap dan karakter yang berpegang pada kebenaran "ujilah segala sesuatu dan peganglah yang baik" (1 Tes. 5:21).

Gereja dengan tugas penyelenggaraan pendidikan agama Kristen berada di tengah isu-isu kontemporer yang menerpa jemaatnya sehingga Gereja pun harus beradaptasi dengan cara-cara yang efektif dalam pembinaan iman umat, seperti kebijakan karantina yang sekarang terjadi akibat pandemi covid-19. Sehingga gereja dituntut berkreasi untuk memelihara dan memenuhi kebutuhan rohani umatnya melalui penggunaan aplikasi media sosial, a.l. youtube, live-streaming, ig, wa, google-classroom, dll yang sesuai dengan kondisi keterjangkauan masing-masing umat.

Generasi milenial yang bercirikan ekspresif, partisipatif, kreatif, lentur, bebas, tidak umum (out of the box), sifatnya kesementaraan- kontemporer, rapuh, dan dangkal sangat rawan terpengaruh oleh gelombang informasi yang sarat dengan nilai budaya asing melalui gadget di tangannya. Dimana topik, tema dan durasi dari konten vlog, youtube, platform pendidikan, umumnya tidak lebih dari lima menit sehingga pengunjung yang mengakses, berpotensi sekedar dipuaskan pada ranah mengetahui dan tidak sampai pada proses penyelidikan bagi penguasaan konsep-logis untuk melatih cara berpikir yang kritis. Hasil survei Bilangan Research Center $^{32}$ tentang spiritualitas generasi muda Kristen Indonesia yang berhubungan dengan media yaitu penggunaan internet, memperoleh data dari total 4.095 responden, ternyata $97.4 \%$ responden terkoneksi dengan internet; $37.3 \%$ aktif sebagai pengguna, $37.3 \%$ biasa saja dan ditinjau dari konten yang dilihatnya menunjukkan bahwa $43 \%$ pernah berakses dengan situs pornografi.

Konten terhadap dan pemahaman kebenaran Alkitab sebagai sumber pengajaran iman pada pengguna sosial media, internet, web, vlog, youtube, dan media inter-koneksi yang berjangkauan luas, memungkinkan akses dan penetrasi informasinya bersifat prematur dan lemah bahkan menyesatkan. Sehingga walaupun teknologi informasi dapat menjadi sarana bagi pendewasaan iman, namun tidak seefektif pembelajaran yang terjadi langsung dalam komunitas tatap muka yang mungkin suatu saat memerlukan "human-touch" seperti bersalaman untuk menyatakan sambutan dan penerimaan, atau menyentuh bahu pada sesama jenis kelamin sebagai ungkapan simpati atau penguatan bagi situasi yang dihadapinya.

Perintah pengajaran yang disebut Syema (Ulangan 6:1-9) mengandung strategi pembelajaran yang efektif dalam pendidikan agama Kristen karena proses pembelajaran yang harus diulang-ulang

\footnotetext{
${ }^{32}$ Vidyatama David, 163.
} 
sehingga memerlukan kreativitas bagi pelbagai peserta didik yang berbeda satu dengan yang lain seperti ada yang belajar maksimal melalui proses menggunakan audio, video atau kinestetik. Parulian ${ }^{33}$ menawarkan strategi pembelajaran yang sedang marak menggunakan media digital yaitu program Superbook. Program dengan konten animasi-media digital ini merupakan program pembelajaran yang dapat memberi pengalaman menarik sehingga diharapkan mampu meningkatkan keimanan generasi alpha (lahir tahun 2011-2025) yang jumlahnya 2.5 juta kelahiran setiap minggunya sehingga pada tahun 2025 jumlah mereka menjadi 2 miliar. Sehingga daya tarik program ini mampu meminimalisir dampak negatif akibat massivenya teknologi digital yang sangat agresif menawarkan program-program yang menina-bobokan generasi milenial dari kenyataan hidup yang sebenarnya dan keimanan yang diperkokoh dalam menjalani kehidupan yang riil.

Perubahan sosial merupakan tantangan bagi pendidikan Agama Kristen yang bertanggung jawab membekali peserta didik dengan saringan untuk menerima informasi yang muncul di dunia maya, sehingga mereka berketahanan menghadapi gelombang isu-isu yang mengaburkan dan melemahkan iman Kristen sesuai surat Rasul Paulus (Efs. 6:10-17) tentang kemendesakkan menggunakan perlengkapan senjata Allah dan teladan Tuhan Yesus dalam menghadapi pencobaan (Mat. 4:1-11). Salah satu dampak buruk dari perkembangan teknologi digital yaitu merebaknya paham atheis yang menyatakan Tuhan tidak ada karena Tuhan tidak dapat dibuktikan keberadaannya melalui iptek. Sia ${ }^{34}$ memaparkan sebuah strategi Pendidikan Agama Kristen yang disebut Mateto. Program ini merupakan pemuridan anak dan remaja yang dilakukan sekali seminggu selama 90 menit dengan menyajikan materi bina kontekstual masyarakat setempat, antara lain topik bahasannya tentang mencari kebenaran Alkitab dan sains tentang kemajemukan agama-agama di Indonesia.

Pendidikan yang mengutamakan penghayatan dan aktualisasi diri dari nilai menjadi "garam dan terang dunia" (Mat. 5:13-16) berkontribusi untuk mempertahankan eksistensi diri dalam mengemban Amanat agung (Mat. 28:19-20) dengan perintah 'pergilah' (mencari peserta didik), 'jadikanlah' (sebagai murid dalam keberlangsungan proses pembelajaran), 'baptislah' (tempatkan dalam suatu komunitas gereja untuk bertumbuh dalam proses pembelajaran yang berkelanjutan sepanjang hayat), 'ajarlah' (untuk terus berubah menuju pertumbuhan menuju kedewasaan iman), 'ketahuilah' dengan kesadaran akan janji penyertaan yang berlangsung sampai akhir zaman.

\section{KESIMPULAN}

Potret pendidikan Indonesia ditinjau dari jumlah pengangguran dan kompetensi guru yang memprihatinkan menunjukkan adanya kemendesakkan terjadinya reformasi pada tatanan praktik pendidikan secara menyeluruh mulai dari kebijakan pemerintah dengan perubahan pola pikir digital sampai menghasilkan output yang sesuai ketetapan undang-undang dalam menjalani era revolusi industri 4.0 dan bahkan siap memasuki era supersmart society 5.0. Generasi milenial yang merupakan aset bangsa dengan segala kreativitas dan multi kecerdasannya sebagai native-digital sekalipun tetap perlu mendapat bimbingan dan pendampingan serta teladan kehidupan pendidik yang profesional melalui relasi kemanusiaan dengan dasar iman yang kokoh sebagai umat beragama dan sokoguru pendidikan.

Perubahan sosial merupakan anak kandung revolusi teknologi yang berpotensi positif dan negatif sekaligus tantangan bagi segenap insan pendidik agama Kristen untuk hadir dan menghidupinya dalam terang kebenaran Alkitab. Pendidikan Agama Kristen bertanggung jawab untuk berbenah diri dalam penyelenggaraan pembelajaran dengan teknologi digital walaupun tetap mempertahankan komunikasi dengan sentuhan kemanusiaan yang relatif masih diperlukan dalam melakukan pembinaan dan pemeliharaan iman. Karena hakekat Pendidikan Agama Kristen untuk memfasilitasi peserta didik mengalami perjumpaan dengan Allah secara pribadi baik melalui

${ }^{33}$ Parulian Yohanes Patar, Dampak Pembelajaran Digital Superbook Terhadap Pertumbuhan Iman Generasi Alpha “PPS-UKI 2018."," In Membangun Indonesia Di Era Revolusi Industri 4.0., (Jakarta: Universitas Kristen Indonesia, 2018), 160.

${ }^{34}$ Luisye Sia, "Program Mateto Dalam Menghadapi Ateisme Di Era Revolusi Industri 4.0.” In Membangun Indonesia Di Era Revolusi Industri 4.0., 179. Jakarta: Universitas Kristen Indonesia, $2018,179$. 
kehadiran pendidik maupun dalam kemandiriannya dalam pembelajaran sepanjang hayat, sehingga keberlangsungan pewarisan nilai-nilai Kristen akan melahirkan generasi yang kuat, militan, tangguh, serta berhikmat dalam menghadapi perkembangan dan perubahan zaman yang telah mendisrupsi segala bidang kehidupan secara eksponential dengan potensi menggoyahkan iman dan mengikis rasa kebangsaan sebagai warga negara Republik Indonesia.

\section{REFERENSI}

Akhmad, Sudrajat. "4 Prinsip Pokok Pembelajaran Abad Ke-21.” Last modified 2013. https:/akhmadsudrajat.wordpress.com/2013/10/01/prinsip-pembelajaran-abad-ke-21/.

Antone, Hope S. Pendidikan Kristiani Kontekstual: Mempertimbangkan Realitas Kemajemukan Dalam Pendidikan Agama. Jakarta: BPK Gunung Mulia, 2010.

Cendekia, J Jasmine - Bandung: Nuansa, and Undefined 2012. Metode Mengajar Multiple Intelligences. Bandung: Penerbit Nuansa, 2016.

Daryanto, and Syaiful Karim. Pembelajaran Abad 21. Gaya Media. Yogyakarta: Penerbit Gava Media, 2017.

David, Vidyatama. "PAK Ramah Digital: Strategi Pendidikan Agama Kristen Bagi Generasi Z Di Gereja Baptis Indonesia Getsemani Jakarta.” In In Membangun Indonesia Di Era Revolusi Industri 4.0, 300. Jakarta: Universitas Kristen Indonesia, 2018.

Dinillah, Mukhlis. "Duh! Gegara Kecanduan Gadget, Bocah 5 Tahun Di Jabar Alami Masalah Kejiwaan." DetikNews. Last modified 2019. https://news.detik.com/berita-jawa-barat/d4741179/duh-gegara-kecanduan-gadget-bocah-5-tahun-di-jabar-alami-masalah-kejiwaan.

Eko, Kristianto Paulus. "Menjadi Homo Informaticus: Pendidikan Agama Kristen Untuk Remaja Di Era Kecerdasan Buatan.”.” In Membangun Indonesia Di Era Revolusi Industri 4.0, 300. Jakarta: Universitas Kristen Indonesia, 2018.

Ghufron, M A. "Revolusi Industri 4.0: Tantangan, Peluang Dan Solusi Bagi Dunia Pendidikan." Seminar Nasional dan Diskusi Panel Multidisiplin Hasil Penelitian dan Pengabdian kepada Masyarakat (2018): 332-337.

Groome, Thomas H. Christian Religious Education. Jakarta: BPK Gunung Mulia, 2011.

Hasna, Wijayati. “Tokoh Sosiologi Emile Durkheim Dan Pemikirannya.” Last modified 2017. https://portal-ilmu.com/tokoh-sosiologi-emile-durkheim/.

Kementerian Pendidikan Nasional. "UU Nomor 20 Tahun 2003 Tentang Sistem Pendidikan Nasional," 2003. http://kemenag.go.id/.

Lase, Delipiter. "Pendidikan Di Era Revolusi Industri 4.0." SUNDERMANN: Jurnal Ilmiah Teologi, Pendidikan, Sains, Humaniora dan Kebudayaan 1, no. 1 (2019): 28-43.

Mariani, Harmadi. "Kurikulum Pendidikan Agama Kristen Yang Adaptif Dan Antisipatif Di Era Revolusi Industri 4.0.” In Membangun Indonesia Di Era Revolusi Industri 4.0.,. Jakarta: Universitas Kristen Indonesia, 2018.

Merdiana, Tantri Novita. Efektivitas Kurikulum 2013 Bagi Sekolah Menengah Kejuruan Dan Tantangan Revolusi Industri 4.0." In Membangun Indonesia Di Era Revolusi Industri 4.0. Jakarta: Universitas Kristen Indonesia, 2018.

Netral, Agus. "Bonus Demografi Dan Beban Pengangguran.” Kompasiana. Last modified 2012. https://www.kompasiana.com/agusnetral6407/5db9435cd541df64e2390412/bonusdemografi-dan-beban-pengangguran?page $=$ all.

Patar, Parulian Yohanes. Dampak Pembelajaran Digital Superbook Terhadap Pertumbuhan Iman Generasi Alpha 'PPS-UKI 2018.'” In Membangun Indonesia Di Era Revolusi Industri 4.0.,. Jakarta: Universitas Kristen Indonesia, 2018.

Pramudya, Angga. "Penyalahgunaan Internet Di Kalangan Remaja." Academia. 
https://www.academia.edu/36272147/PENYALAHGUNAAN_INTERNET_DI_KALANGA $\mathrm{N}$ REMAJA.

Saragih, A. Hasan. "Kompetensi Minimal Seorang Guru Dalam Mengajar." Jurnal Tabularasa 5, no. 1 (2008): 23-34.

Sidjabat, Binsen Samuel. "Kerangka Kurikulum Pendidikan Agama Kristen Berbasis Karakter Di Perguruan Tinggi Character-Based Christian Religious Education Curriculum Framework in Higher Education." Jurnal Jaffray 17, no. 1 (2019): 73-90.

Syamsuar, and Reflianto. "Pendidikan Dan Tantangan Pembelajaran Berbasis Teknologi Informasi Di Era Revolusi Industri 4.0." Pendidikan Dan Tantangan Pembelajaran Berbasis Teknologi Informasi Di Era Revolusi Industri 4.0 6, no. 2 (2019): 1-13.

Tribunnews.Com. "Jumlah Pendaftar Dan Formasi Cpns 2019."

Wardani, Agustin Setyo. "Kematian Tragis Akibat Smartphone.” Last modified 2017. https://www.liputan6.com/tekno/read/3022645/10-kematian-tragis-akibat-smartphone.

Wijayakusuma. "Masyarakat Masih Gagal Paham Dengan Perubahan Era Industri 4.0." 14 Agustus, 2019. https:/economy.okezone.com/read/2019/08/14/320/2091635/masyarakat-masih-gagalpaham-dengan-perubahan-era-industri-4-0.

Yuswohadi. "Nadiem Dan Disrupsi Pendidikan Kita.” Accessed May 18, 2020. https://www.yuswohady.com/2019/10/25/nadiem-dan-disrupsi-pendidikan-kita/.

Zaluchu, Sonny. "The Digital Mindset as an Approach to Education Forthe Millenial Generation." In ICOGESS, edited by Suardin Gaurifa. Medan: EAI, 2020. https://eudl.eu/doi/10.4108/eai.14-3-2019.2292036.

"Pendaftar CPNS Tembus 5 Juta Pelamar." Kompas.Com. Last modified 2019. https://sains.kompas.com/read/2019/11/28/070106826/pendaftar-cpns-tembus-5-juta-pelamarbkn-akan-maintenance-website.

“PP No. 55 Tahun 2007.” BPK.Go.Id. https://peraturan.bpk.go.id/Home/Details/4777/pp-no-55tahun-2007.

"Salinan Lampiran I Peraturan Menteri Pendidikan Dan Kebudayaan Nomor 34 Tahun 2018 Tentang Standar Nasional Pendidikan Sekolah Menengah Kejuruan/Madrasah Aliyah Kejuruan Standar Kompetensi Lulusan.” Jdih.Kemdikbud.Go.Id. https://jdih.kemdikbud.go.id/arsip/Permendikbud Nomor 34 Tahun 2018.pdf.

"Sembilan Kasus Pembunuhan Akibat Video Game." Liputan 6. https://www.liputan6.com/citizen6/read/2287867/9-kasus-pembunuhan-akibat-video-game. 